\title{
Pengaruh Kekayaan Daerah dan Belanja Modal Terhadap Kinerja Penyelanggaraan Pemerintah: Pengujian Legislative Power Sebagai Variabel Pemoderasi
}

\author{
Regina Usman ${ }^{1}$ \\ Fakultas Ekonomi \\ Universitas Andalas, Indonesia. \\ Email: reginauman77@gmail.com
}

\author{
Fauzan Misra ${ }^{2}$ \\ Fakultas Ekonomi \\ Universitas Andalas, Indonesia.
}

\author{
Firdaus $^{3}$ \\ Fakultas Ekonomi \\ Universitas Andalas, Indonesia.
}

\begin{abstract}
ABSTRAK
Penelitian ini bertujuan untuk menguji pengaruh kekayaan daerah dan belanja modal terhadap kinerja penyelenggaraan pemerintah daerah, selanjutnya untuk melihat apakah legislative power mempengaruhi hubungan antara kekayaan daerah dan belanja modal terhadap kinerja penyelenggaraan pemerintah daerah. Populasi dalam penelitian ini adalah seluruh pemerintah provinsi di Indonesia tahun 2011 - 2015. Kriteria pengambilan sampel yang digunakan adalah teknik purposive sampling dan diperoleh 149 observasi. Alat analisis yang digunakan Moderate Regression Analysis. Hasil penelitian kekayaan daerah tidak berpengaruh terhadap kinerja penyelenggaraan pemerintah daerah, sedangkan belanja modal berpengaruh terhadap kinerja penyelenggaraan pemerintah daerah. Legislative power tidak memoderasi hubungan antara kekayaan daerah dengan kinerja penyelenggaraan pemerintah daerah. Hasil penelitian juga menunjukkan bahwa legislative power memperlemah hubungan antara belanja modal dengan kinerja penyelenggaraan pemerintah daerah.
\end{abstract}

Kata Kunci: Kekayaan Daerah, Belanja Modal, Legislative Power dan Kinerja Penyelenggaraan Pemerintah Daerah.

The Effect Of Regional Wealth And Capital Expenditure On Performance: Testing Legislative Power As A Moderating Variable

\section{ABSTRACT}

This study aims to examine the effect of regional wealth and capital expenditure on the performance of local government administration, then to see whether legislative power affects the relationship between regional wealth and capital expenditure on the performance of local government administration. The population in this study were all provincial governments in Indonesia in 2011 2015 as many as 170 populations. The sampling criteria used were purposive sampling techniques to obtain a sample of 149 observations. This research uses the Moderate Regression Analysis method. The results showed that regional wealth did not affect the performance of regional government operations, while capital expenditure had a positive and significant effect on the performance of regional government operations. Legislative power does not moderate the relationship between regional wealth and the performance of government operations. Also, legislative power can weaken the relationship between capital expenditure and the performance of government operations.

Keywords: Regional Wealth, Capital Expenditures, Legislative Power and Performance of Local Government Operation

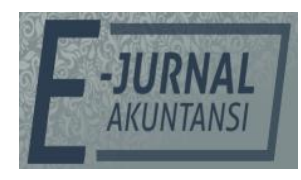

E-JA

e-Jurnal

Akuntansi

e-ISSN 2302-8556

Vol. 29 No. 2

Denpasar,

November 2019

Hal. 561-576

Artikel masuk:

23 Juli 2019

Tanggal diterima:

18 November

2019 


\section{PENDAHULUAN}

Indonesia merupakan negara kesatuan yang menganut sistem desentralisasi dalam penyelenggaraan pemerintahannya. Sistem desentralisasi tersebut memberikan kewenangan kepada daerah untuk menyelenggarakan otonomi daerah. Otonomi daerah merupakan hak, wewenang serta kewajiban dari suatu daerah otonom untuk mengatur dan mengurus sendiri urusan pemerintahannya sesuai dengan peraturan perundang-undangan yang berlaku (UU No.32 Tahun 2004). Pemindahan wewenang dari pemerintah pusat kepada pemerintah daerah dilakukan agar pemerintah daerah dapat mengatur serta mengurus urusan daerahnya secara mandiri.

Demi tercapainya otonomi daerah yang sejalan dengan upaya untuk menciptakan tata kelola pemerintahan yang baik, maka kepala daerah diwajibkan untuk melaporkan penyelenggaraan pemerintahannya. Pemerintah daerah mempunyai kewajiban untuk mempertanggungjawabkan tata kelola pemerintahannya dalam bentuk Laporan Penyelenggaraan Pemerintah Daerah (LPPD) . LPPD berisikan informasi yang akurat dan memadai mengenai penyelenggaraan pemerintah daerah selama satu tahun anggaran (UU No.23 Tahun 2014). Semua kepala daerah wajib untuk menyerahkan LPPD kepada pemerintah pusat dengan tujuan untuk mengetahui pengelolaan dan pertanggungjawaban kinerja pemerintah daerah tersebut. LPPD dapat dijadikan sebagai bahan evaluasi untuk keperluan pembinaan dan pengembangan pada daerah tersebut.

Pemerintah pusat mempunyai kewajiban untuk melakukan evaluasi terhadap kinerja penyelenggaraan pemerintah daerah atau yang dapat disebut dengan Evaluasi Kinerja Penyelenggaraan Pemerintah Daerah (EKPPD). Menurut Permendagri No. 73 Tahun 2009 EKPPD merupakan proses mengumpulkan dan menganalisis data yang digunakan secara sistematis terhadap kinerja penyelenggaraan pemerintah daerah, dimana proses ini menggunakan sistem pengukuran kinerja. Dalam melakukan EKPPD, pemerintah pusat menggunakan LPPD sebagai sumber informasi utama. EKPPD juga menggunakan beberapa sumber informasi pelengkap lainnya seperti laporan APBD, Laporan Kinerja Instansi Pemerintah Daerah, informasi keuangan daerah serta survey kepuasan masyarakat terhadap pelayanan yang diberikan oleh pemerintah daerah.

EKPPD merupakan hal yang sangat penting untuk melihat keberhasilan suatu daerah dalam melaksanakan otonomi daerahnya. Hasil EKPPD menghasilkan status prestasi dengan skor kinerja sangat tinggi, tinggi, sedang dan rendah. Pemerintah daerah dapat melakukan tindaklanjut terhadap hasil EKPPD dengan cara melakukan program pengembangan kapasitas untuk meningkatkan kinerja. Bagi daerah yang memiliki kinerja dengan kategori yang rendah maka pemerintah akan menyiapkan pembinaan serta fasiltas khusus. 


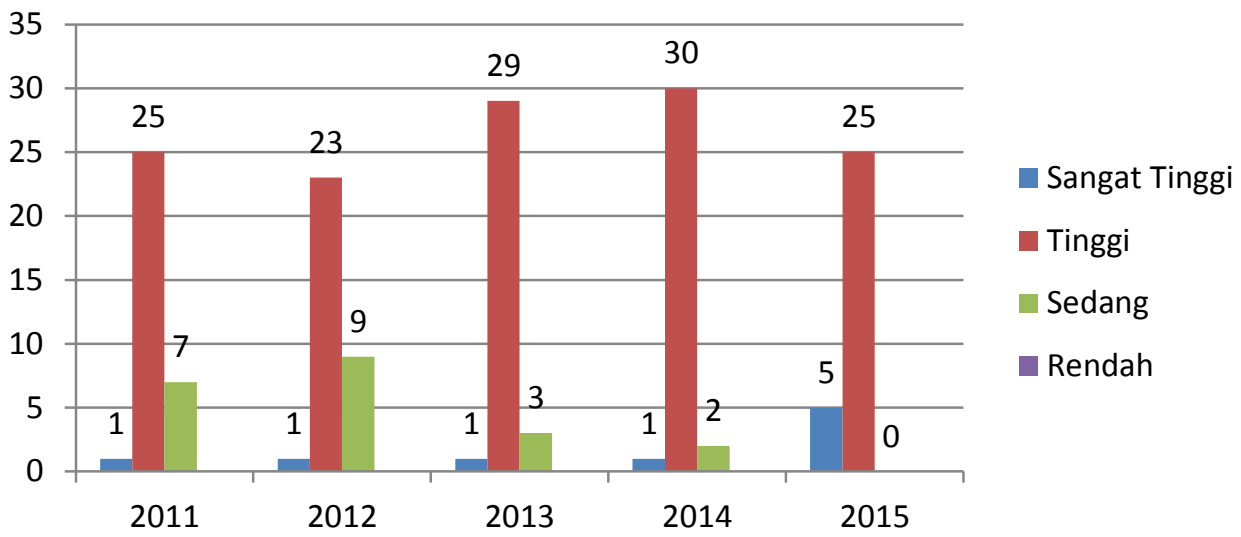

Gambar 1. EKPPD terhadap LPPD Provinsi di Indonesia Tahun 2011-2015 Sumber : Kementerian Dalam Negeri Republik Indonesia, 2019

Berdasarkan Gambar 1 dapat dilihat bahwa selama tahun 2011 hingga tahun 2014 hanya satu dari 33 provinsi yang memiliki kinerja sangat tinggi, yaitu Provinsi Jawa Timur. Pada tahun 2015 provinsi yang memperoleh skor kinerja sangat tinggi meningkat menjadi lima provinsi yaitu Provinsi Jawa Timur, Jawa Barat, Kalimantan Timur, DKI Jakarta dan Jawa Tengah. Pada Gambar 1 juga dapat dilihat dari tahun 2011 hingga tahun 2014 masih terdapat beberapa provinsi yang memiliki kinerja dengan kategori sedang. Hal ini menandakan masih lemahnya komitmen pemerintah daerah tersebut dalam mewujudkan tata kelola pemerintahan yang baik. Pemerintah daerah diharapkan dapat memberikan kinerja terbaiknya setiap tahun kepada masyarakat. Semakin tingginya skor kinerja pemerintah daerah menandakan bahwa semakin baiknya pelayanan yang diberikan kepada masyarakat (Mustikarini dan Fitriasari, 2012).

Menurut Mustikarini dan Fitriasari (2012) salah satu faktor yang dapat mempengaruhi skor kinerja penyelenggaraan pemerintah daerah adalah kekayaan daerah. Untuk dapat memberikan pelayanan yang baik kepada masyarakat maka harus didukung dengan kekayaan yang dimiliki oleh pemerintah daerah tersebut. Daerah yang memiliki kekayaan yang besar akan mempunyai kemampuan lebih baik dalam memberikan pelayanan kepada masyarakat. Kekayaan daerah dapat diukur dengan total aset yang dimiliki oleh daerah tersebut (Armaja et al., 2015). Total aset yang besar diharapkan dapat memberikan kemudahan operasional dan pelayanan yang memadai kepada masyarakat. Kemudahan operasional dapat memberikan kelancaran dalam memperoleh Pendapatan Asli Daerah (PAD), dimana hal ini akan mendorong peningkatan pembangunan dan infrastruktur di daerah yang akan diikuti oleh peningkatan kinerja penyelenggaraan pemerintah daerah tersebut. Besarnya total aset yang dimiliki oleh organisasi dapat membuat organisasi tersebut memiliki tekanan yang besar dari publik untuk melaporkan pengungkapan wajibnya (Cooke, 1992). Hal ini membuat pemerintah akan cenderung berupaya memberikan good news dalam mengungkapkan laporan keuangannya, good news tersebut dapat berupa laporan mengenai baiknya kinerja pemerintah daerah tersebut (Sumarjo, 2010).

Beberapa penelitian mengenai pengaruh kekayaan daerah terhadap kinerja penyelenggaraan daerah telah dilakukan. Berdasarkan penelitian yang dilakukan 
oleh Kusumawardani (2012), Siddi (2016), Widagdo (2017), Mustikarini dan Fitriasari (2012) dan Sijabat (2016) menyatakan bahwa kekayaan daerah yang dilihat dari total aset memiliki pengaruh positif terhadap kinerja penyelenggaraan pemerintah daerah. Hal ini menandakan bahwa semakin besarnya total aset yang dimiliki oleh daerah akan mampu untuk meningkatkan kinerja penyelenggaraan pemerintah daerah tersebut. Berbeda dengan temuan tersebut, penelitian yang dilakukan oleh Nugroho dan Prasetyo (2018), Harumiati dan Payamta (2014), Renas dan Muid (2014) dan Febrianto (2018) menemukan bahwa kekayaan daerah yang dilihat dari total aset daerah tidak berpengaruh terhadap kinerja penyelenggaraan pemerintah daerah.

Belanja modal juga merupakan salah satu faktor yang dapat mempengaruhi kinerja penyelenggaraan pemerintah daerah. Belanja modal dapat digunakan untuk membiayai kegiatan-kegiatan yang mengarah kepada kepentingan publik. Menurut Sudarsana dan Rahardjo (2013) belanja modal sangat berkaitan dengan penyediaan fasilitas dan infrastruktur yang berhubungan langsung dengan pelayanan kepada masyarakat. Besarnya jumlah belanja modal dapat mencerminkan semakin banyaknya sarana dan infrastruktur yang dibangun untuk kepentingan masyarakat. Dengan semakin banyaknya pembangunan yang dilakukan oleh pemerintah daerah, maka akan meningkatkan pelayanan pemerintah daerah terhadap masyarakat sehingga kinerja penyelenggaraan pemerintah juga akan menjadi lebih baik.

Berdasarkan penelitian yang dilakukan oleh Andirfa et al. (2016), Alvini et al. (2018), Leki et al. (2018) dan Mangkunegara (2015) menyatakan bahwa belanja modal berpengaruh positif terhadap kinerja pemerintah daerah. Hal ini menandakan bahwa semakin besar belanja modal maka kinerja penyelenggaraan pemerintah daerah juga akan semakin meningkat. Namun berdasarkan penelitian yang dilakukan oleh Sudarsana dan Rahardjo (2013) serta Harumiati dan Payamta (2014) menyatakan bahwa belanja modal tidak berpengaruh terhadap kinerja penyelenggaraan daerah.

Beberapa penelitian mengenai faktor-faktor yang mempengaruhi kinerja penyelenggaraan pemerintah daerah telah dilakukan namun masih terdapat inkonsistensi dari penelitian-penelitian sebelumnya. Penelitian-penelitian terdahulu juga belum mempertimbangkan faktor legislative power terhadap peningkatan kinerja penyelenggaraan pemerintah. Menurut Misra (2008) dan Cheng (1992) legislative power dapat diproksikan dengan jumlah anggota legislatif. Dengan semakin banyaknya jumlah anggota legislatif maka pengawasan terhadap seluruh kegiatan penyelenggaraan pemerintah juga akan semakin besar. Besarnya jumlah anggota legislatif juga dapat memberikan tekanan kepada pemerintah untuk dapat meningkatkan kinerjanya. Hal ini disebabkan karena lembaga legislatif merupakan wakil rakyat yang mempunyai fungsi pengawasan terhadap jalannya pemerintahan agar sesuai dengan aspirasi masyarakat atau konstituen yang telah memilihnya.

Penelitian terdahulu yang berkaitan dengan faktor-faktor yang mempengaruhi kinerja penyelenggaraan pemerintah daerah telah banyak dilakukan pada pemerintah kabupaten/kota. Masih sedikitnya penelitian terkait pada tingkat provinsi membuat penulis tertarik untuk melakukan penelitian ini pada semua provinsi yang ada di Indonesia. Selama ini otonomi daerah lebih 
dititikberatkan kepada pemerintah kabupaten/kota dibandingkan kepada pemerintah provinsi. Hal ini menyebabkan efekfitas dan stabilitas penyelenggaraan pemerintah di tingkat provinsi masih belum berjalan dengan sebagaimana mestinya, ini juga dapat dibuktikan dari data EKPPD yang diperoleh dari Kemendagri dimana rata-rata kinerja penyelenggaraan pemerintah provinsi lebih rendah dibandingkan dengan kinerja penyelenggaraan pemerintah kabupaten/kota yang ada di Indonesia.

Tujuan dari penelitian ini adalah untuk menguji pengaruh kekayaan daerah dan belanja modal terhadap kinerja penyelenggaraan pemerintah daerah. Penelitian ini juga bertujuan untuk menguji apakah legislative power mampu memperkuat hubungan antara masing-masing variabel independen terhadap varibel dependen. Temuan ini diharapkan dapat memberikan kontribusi untuk memperkaya literatur tentang faktor-faktor yang mempengaruhi kinerja penyelenggaraan pemerintah daerah. Hasil dari penelitian ini juga akan memberikan konfirmasi tentang konsistensi dari variabel kekayaan daerah yang menurut resource-based view berpengaruh terhadap kinerja penyelenggaraan pemerintah daerah. Disamping itu, temuan dalam penelitian ini akan memberikan konfirmasi mengenai konsistensi dari variabel belanja modal yang menurut Median Voter Model memiliki pengaruh positif terhadap kinerja penyelenggaraan pemerintah daerah. Penelitian ini juga akan memberikan konfirmasi tentang konsistensi dari variabel legislative power yang menurut teori keagenan dapat memoderasi pengaruh tingkat kekayaan daerah dan belanja modal terhadap kinerja penyelenggaraan pemerintah daerah.

Kekayaan merupakan sumber daya yang dimiliki oleh pemerintah untuk memberikan pelayanan kepada masyarakat. Pemerintah daerah yang mempunyai kekayaan lebih besar dapat memberikan pelayanan yang lebih baik kepada masyarakat dibandingkan dengan pemerintah daerah yang memiliki kekayaan kecil. Kekayaan dapat dilihat dari total aset yang dapat menggambarkan besarnya sumber daya yang dimiliki oleh suatu daerah (Armaja et al., 2015). Menurut PSAP aset merupakan sumber daya ekonomi yang dimiliki dan dikuasai oleh pemerintah atas akibat dari kejadian di masa lalu dan diharapkan pemerintah dan masyarakat dapat memperoleh manfaat ekonomi di masa depan.

Pemerintah dapat memberikan pelayanan yang baik kepada masyarakat jika didukung dengan aset yang baik pula. Total aset yang dimiliki oleh pemerintah daerah diharapkan dapat memberikan kemudahan operasional dan memberikan pelayanan yang memadai kepada masyarakat. Kemudahan operasional dapat memberikan kelancaran dan peningkatan dalam memperoleh penerimaan PAD. Jika penerimaan PAD meningkat maka akan mendorong meningkatnya pembangunan baik berupa sarana dan prasarana untuk kepentingan masyarakat yang kemudian akan diikuti dengan meningkatnya kinerja penyelenggaraan pemerintah daerah.

Berdasarkan perspektif resource-based view theory, kinerja organisasi akan berbeda-beda tergantung kepada sumber daya yang dimiliki organisasi tersebut. Dalam hal ini yang dimaksud sumber daya adalah total aset. Semakin besar total aset yang dimiliki pemerintah daerah diharapkan dapat memberikan pelayanan dan jasa yang lebih baik kepada masyarakat, sehingga nantinya akan berdampak 
pada peningkatan kinerja penyelenggaraan pemerintah daerah. Berdasarkan uraian tersebut maka hipotesis pertama dalam penelitian ini adalah:

$\mathrm{H}_{1}$ : Kekayaan daerah berpengaruh positif terhadap kinerja penyelenggaraan pemerintah daerah.

Berdasarkan teori pengeluaran pemerintah, pengeluaran pemerintah merupakan pengeluaran yang dilakukan berdasarkan kepada keputusan yang dibuat oleh pemerintah dengan tujuan untuk menyediakan barang-barang serta pelayanan kepada pemerintah. Menurut Lee dan Plummer (2007) terdapat teori perilaku pemerintah dalam menentukan anggaran keluaran pemerintah yaitu Median Voter Model. Model ini menjelaskan bahwa pemerintah akan berupaya untuk bertindak sesuai dengan kepentingan terbaik konstituennya dalam menentukan anggaran belanja yang akan dikeluarkan.

Menurut Darise (2007) belanja modal merupakan pengeluaran yang dilakukan dalam rangka pembentukan yang dapat memberikan manfaat lebih dari 1 (satu) periode akuntansi. Belanja modal dapat digunakan oleh pemerintah untuk meningkatkan kualitas hidup masyarakat dalam bentuk penyediaan pelayanan dasar, pendidikan, penyediaan fasilitas kesehatan yang memadai serta fasilitas umum lain yang layak. Kegiatan belanja modal juga dapat digunakan untuk membiayai proyek-proyek yang bertujuan untuk meningkatkan kesejahteraan dan kepentingan masyarakat.

Salah satu indikasi keberhasilan penyelenggaraan pemerintah daerah adalah banyaknya infrastruktur yang dibangun yang dapat tercermin dari besarnya belanja modal dalam APBD (Artha et al., 2015). Pemerintah daerah akan berupaya untuk meningkatkan anggaran belanja modalnya dengan tujuan untuk memberikan pelayanan yang terbaik kepada masyarakat. Belanja modal dapat digunakan oleh pemerintah untuk meningkatkan pembanganan infrastruktur pada suatu daerah. Jika semakin banyak pembangunan infrastruktur yang dilakukan oleh pemerintah (agent), maka akan membuat semakin meningkatnya pelayanan yang diberikan pemerintah daerah kepada masyarakat (principal) yang kemudian akan berdampak kepada peningkatan kinerja penyelenggaraan pemerintah daerah. Berdasarkan uraian tersebut maka hipotesis kedua dalam penelitian ini adalah:

$\mathrm{H}_{2}$ : Belanja modal berpengaruh positif terhadap kinerja penyelenggaraan pemerintah daerah.

Legislative power memegang peranan penting terhadap peningkatan kinerja penyelenggaraan pemerintah daerah. Dewan Perwakilan Rakyat Daerah (DPRD) atau anggota legislatif merupakan lembaga perwakilan rakyat yang sekaligus mempunyai kedudukan sebagai unsur penyelenggaraan pemerintah daerah (UU No.32 Tahun 2004). Menurut Misra (2008) legislatif yang kuat akan melaksanakan fungsi pengawasannya dengan baik. Pengawasan yang dilakukan oleh legislatif terhadap setiap kebijakan dan aktivitas yang dilakukan oleh eksekutif ditujukan untuk menjamin bahwa pemerintahan telah berjalan sesuai dengan rencana dan peraturan perundang-undangan yang berlaku sehingga nantinya akan diikuti oleh meningkatnya kinerja penyelenggaraan pemerintah.

Teori keagenan menjelaskan terdapat hubungan keagenan antara legislatif dengan eksekutif (pemerintah). Dalam hubungan tersebut, pemerintah merupakan agen sementara masyarakat merupakan principal. Masyarakat tidak 
dapat melakukan pengawasan secara langsung terhadap kegiatan pemerintah, untuk itu masyarakat membutuhkan peran legislatif dalam melakukan pengawasan terhadap pemerintah. Kekayaan daerah perlu menjadi perhatian legislatif dalam penyelenggaraan pemerintahan. Kekayaan daerah yang diukur dari total aset perlu dikelola dengan baik agar dapat memberikan kemudahan operasional dan memberikan pelayanan yang baik kepada masyarakat.

Legislative power dapat diproksikan dengan jumlah anggota legislatif. Dengan semakin banyaknya jumlah anggota legislatif maka pengawasan yang akan dilakukan terhadap kekayaan daerah juga akan semakin meningkat. Besarnya pengawasan terhadap kekayaan daerah diharapkan dapat mengurangi terjadinya asimetri informasi berupa penyalahgunaan aset daerah serta memastikan bahwa total aset yang ada benar-benar dimanfaatkan sesuai dengan fungsinya. Berdasarkan uraian tersebut maka hipotesis ketiga dalam penelitian ini adalah:

$\mathrm{H}_{3}$ : Legislative power memperkuat pengaruh kekayaan daerah terhadap kinerja penyelenggaraan pemerintah daerah.

Belanja modal merupakan salah satu kunci keberhasilan kinerja penyelenggaraan pemerintah daerah. Belanja modal digunakan oleh pemerintah untuk kegiatan-kegiatan yang mengarah kepada kepentingan publik. Berdasarkan teori keagenan, pemerintah daerah selaku agen harus dapat mempertanggungjawabkan anggaran belanja modalnya untuk dapat menjalankan program pembangunan yang telah direncanakan. Anggota legislatif juga harus dapat melakukan pengawasan terhadap alokasi belanja modal untuk menjamin tidak adanya asimetri informasi antara pemerintah selaku agen dan masyarakat serta legislatif selaku principal.

Hubungan keagenan juga terjadi antara legislatif dengan masyarakat, dimana legislatif merupakan agen dan masyarakat merupakan principal. Legislatif akan berupaya untuk meningkatkan pengeluaran (belanja modal) sebagai bentuk balas budi (logrolling) kepada masyarakat yang telah memilihnya, sehingga hal ini menjadi alasan mengapa jumlah kursi di legislatif berhubungan positif dengan besarnya belanja modal (Junita dan Abdullah, 2016). Legislatif merupakan pihak yang akan menyetujui atau menolak apa saja yang akan dilakukan oleh pemerintah. Hal ini dilakukan dengan cara menyetujui atau menolak usulan anggaran yang diajukan oleh pemerintah, atas nama rakyat yang diwakilinya. Berdasarkan uraian tersebut maka hipotesis keempat dalam penelitian ini adalah:

H4: Legislative power memperkuat pengaruh belanja modal terhadap kinerja penyelenggaraan pemerintah daerah.

\section{METODE PENELITIAN}

Penelitian ini menggunakan pendekatan kuantitatif. Jenis data yang digunakan dalam penelitian ini adalah data sekunder. Data kekayaan daerah dan belanja modal dalam penelitian ini didapatkan dari Laporan Realisasi APBD dan Neraca tahun 2011 sampai 2015 yang diperoleh dari situs http://www.djpk.depkeu.go.id/. Untuk data skor EKPPD dan legislative power tahun 2011 hingga 2015 diperoleh dari situs resmi Kemendagri http://otda.kemendagri.go.id. 
Populasi dalam penelitian ini adalah seluruh pemerintah provinsi di Indonesia selama tahun 2011 hingga tahun 2015 sebanyak 170 provinsi. Teknik pengambilan sampel dalam penelitian ini adalah teknik purposive sampling. Berdasarkan teknik pengambilan sampel tersebut, maka diperoleh sampel sebanyak 149 provinsi selama lima tahun.

Pengukuran untuk variabel dependen dalam penelitian ini diukur dengan melihat skor hasil evaluasi pemeringkatan kinerja daerah berdasarkan LPPD Tahun 2011 sampai dengan 2015 oleh Kementerian Dalam Negeri. Skor kinerja pemerintah daerah berada dalam range nilai 0-4. Sedangkan untuk variabel moderasi dalam penelitian ini diukur dengan menggunakan jumlah anggota legislatif pada masing-masing daerah.

Variabel kekayaan daerah dapat diukur dengan melihat total aset yang dimiliki oleh daerah tersebut. Dalam penelitian ini penulis akan mentransformasikan total aset yang dimiliki oleh pemerintah daerah kedalam bentuk Logaritma Natural Total Aset. Adapun tujuannya adalah untuk mengurangi fluktuasi data yang berlebih. Untuk variabel belanja modal diukur melalui perbandingan antara jumlah realisasi belanja modal dengan jumlah realisasi belanja daerah pada tahun sebelumnya ( $t-1)$ yang tercantum dalam Laporan Realisasi APBD. Adapun alasan menggunakan tahun sebelumnya disebabkan karena pada umumnya manfaat dari belanja modal baru dapat dirasakan oleh masyarakat pada tahun berikutnya.

Untuk menguji hipotesis yang diajukan dalam penelitian ini, penulis menggunakan model regresi linear berganda dengan metode Moderate Regression Analysis. Penelitian ini juga menggunakan analisis statistik deskriptif untuk melihat nilai rata-rata, standar deviasi, nilai maksimum dan nilai minimum. Dalam penelitian ini juga dilakukan uji koefiesien determinasi untuk melihat seberapa besar hubungan variabel independen, variabel moderasi dan moderat dengan variabel dependen. Berikut merupakan persamaan regresi dalam penelitian ini:

$Y=\alpha+\beta_{1} K D+\beta_{2} B M+\beta_{3} L P+\beta_{4} K D \cdot L P+\beta_{5} B M \cdot L P+e$

Keterangan :

$\mathrm{Y}=$ Skor kinerja penyelenggaraan pemerintah daerah

$\alpha=$ Konstanta

$\beta_{1}=$ Koefisien regresi kekayaan daerah

$\beta_{2}=$ Koefisien regresi belanja modal

$\beta_{3}=$ Koefisien regresi legislative power

$\beta_{4}=$ Koefisien regresi interaksi kekayaan daerah dengan legislative power

$\beta_{5}=$ Koefisien regresi interaksi belanja modal dengan legislative power

$\mathrm{KD}=$ Kekayaan daerah

$\mathrm{BM}=$ Belanja modal

LP = Legislative power

KD.LP = Interaksi kekayaan daerah dengan legislative power sebagai variabel moderating

BM.LP = Interaksi belanja modal dengan legislative power sebagai variabel moderating

e $\quad=$ Koefisien eror 


\section{HASIL DAN PEMBAHASAN}

Statistik deskriptif dalam penelitian ini dilakukan untuk mendeskripsikan data dalam penelitian yang meliputi jumlah sampel, nilai tertinggi, nilai terendah, deviasi standar dan nilai rata-rata. Berikut merupakan hasil pengujian statistik deskriptif:

Tabel 1. Statistik Deskriptif

\begin{tabular}{|c|c|c|c|c|c|}
\hline & $\mathrm{N}$ & Minimum & Maksimum & Rata-rata & $\begin{array}{l}\text { Deviasi } \\
\text { Standar }\end{array}$ \\
\hline $\begin{array}{l}\text { Kekayaan } \\
\text { Daerah }\end{array}$ & 149 & $\begin{array}{l}962.165 .353 . \\
684\end{array}$ & $\begin{array}{l}425.756 .995 . \\
051.083\end{array}$ & $\begin{array}{l}20.183 .721 .328 . \\
312,01\end{array}$ & $\begin{array}{l}63.617 .212 .874 \\
236,71\end{array}$ \\
\hline $\begin{array}{l}\text { Belanja } \\
\text { Modal }\end{array}$ & 149 & ,0597 & ,4150 & 1979 & ,0803 \\
\hline $\begin{array}{l}\text { Legislative } \\
\text { Power }\end{array}$ & 149 & 44 & 100 & 60,3557 & 18,7508 \\
\hline $\begin{array}{l}\text { Kinerja } \\
\text { Pemerintah }\end{array}$ & 149 & 1,3720 & 3,1802 & 2,3851 & 3570 \\
\hline $\begin{array}{l}\text { Valid N } \\
\text { (listwise) }\end{array}$ & 149 & & & & \\
\hline
\end{tabular}

Sumber: Data Penelitian, 2019

Berdasarkan Tabel 1 dapat dilihat bahwa bahwa rata-rata kekayaan daerah pada 34 Provinsi di Indonesia tahun 2011 hingga 2015 adalah sebesar 20.183.721.328.312,01 (DS=63.617.212.874.236,71). Kekayaan daerah terendah adalah sebesar 962.165.353.684 dimiliki oleh provinsi Sulawesi Barat pada tahun 2011. Nilai kekayaan daerah tertinggi mencapai 425.756.995.051.083 dimiliki oleh Provinsi DKI Jakarta tahun 2014.

Belanja modal yang diukur dengan membandingkan jumlah total belanja modal dengan total belanja daerah. Selama tahun 2010 hingga 2015 nilai belanja modal pada 34 Provinsi di Indonesia memperoleh nilai rata-rata sebesar 19,79\% (DS=8,03\%). Nilai belanja modal tertinggi adalah sebesar $41,50 \%$ pada Provinsi Kepulauan Riau tahun 2011. Untuk nilai belanja modal terendah adalah 5,97\% dimiliki oleh provinsi Jawa Tengah tahun 2012.

Variabel legislative power diukur dengan jumlah anggota DPRD pada masingmasing provinsi. Dari Tabel 1 dapat dilihat bahwa nilai rata-rata legislative power pada tahun 2011 hingga 2015 di 34 Provinsi adalah sebesar 60,35 (DS=18,75). Nilai tertinggi dari variabel legislative power adalah sebesar 100, sedangkan nilai terendah dari variabel legislative power adalah sebesar 44 .

Seperti yang dapat dilihat pada Tabel 1, nilai rata-rata kinerja penyelenggaraan pemerintah daerah selama tahun 2011 sampai 2015 adalah sebesar 2,3851 ( $D S=0,3570$ ). Skor kinerja penyelenggaraan pemerintah daerah yang paling tinggi diperoleh oleh Provinsi Jawa Timur pada tahun 2015 yaitu sebesar 3,1802. Skor kinerja penyelenggaraan pemerintah daerah terendah adalah sebesar 1,3720 dimiliki oleh Provinsi Maluku Utara tahun 2012.

Sebelum melakukan analisis regresi maka perlu dilakukan uji asumsi klasik untuk menguji modal regresi yang digunakan yang terdiri dari uji normalitas, uji heteroskedastisitas, uji autokorelasi, uji multikolinieritas. 
Tabel 2. Hasil Pengujian Asumsi Klasik

\begin{tabular}{|c|c|c|c|c|c|}
\hline \multirow[t]{2}{*}{$\begin{array}{l}\text { Parameter } \\
\text { Yang Diuji }\end{array}$} & $\begin{array}{l}\text { Uji } \\
\text { Normalitas }\end{array}$ & $\begin{array}{l}\text { Uji } \\
\text { Heterokedastisitas }\end{array}$ & $\begin{array}{l}\text { Uji } \\
\text { Autokorelasi }\end{array}$ & $\begin{array}{l}\text { Uji } \\
\text { Multikolin }\end{array}$ & ritas \\
\hline & $\begin{array}{l}\text { Asymp Sig } \\
\text { (2-tailed) }\end{array}$ & Sig. (2-tailed) & DW & Tolerance & VIF \\
\hline $\begin{array}{l}\text { Unstandardized } \\
\text { Residual }\end{array}$ & .219 & & & & \\
\hline LnKekayaan & & ,381 & & .515 & 1.940 \\
\hline BelanjaModal & & 849 & & .730 & 1.369 \\
\hline $\begin{array}{l}\text { LegislativePo } \\
\text { wer }\end{array}$ & & 766 & & .393 & 2.543 \\
\hline $\begin{array}{l}\text { Durbin } \\
\text { Watson }\end{array}$ & & & 1.982 & & \\
\hline
\end{tabular}

Sumber: Data Penelitian, 2019

Pengujian normalitas yang dilakukan dalam penelitian ini menggunakan uji statistik non parametrik Kolmogrov-Smirnov (K-S). Dari Tabel 2 dapat terlihat besarnya nilai signifikansi yang diperoleh adalah sebesar 0,219 , dimana nilai ini lebih besar dari 0,05. Hal ini berarti data berdistribusi secara normal.

Uji heterokedastisitas dilakukan dengan melakukan uji Rank Spearman. Model regresi yang baik adalah tidak terdapat gejala heterokedastisitas, dimana tingkat signifikansi harus lebih besar dari 0,05. Berdasarkan Tabel 2 dapat dilihat bahwa nilai signifikansi yang diperoleh oleh semua variabel lebih besar dari 0,05, dimana nilai signifikansi 0,381 untuk variabel kekayaan daerah, 0,849 untuk variabel belanja modal dan 0,766 untuk variabel legislative power. Dapat disimpulkan bahwa tidak terjadi heterokedastisitas pada model regresi.

Uji autokorelasi dalam penelitian ini dilakukan dengan melihat angka Durbin Watson. Nilai Durbin Watson tersebut kemudian dibandingkan dengan nilai $\mathrm{d}_{1}$ dan nilai $\mathrm{d}_{\mathrm{u}}$. Nilai $\mathrm{d}_{1}$ dan $\mathrm{d}_{\mathrm{u}}$ dapat dilihat dari tabel Durbin Watson dengan $\alpha=5 \%, n=$ jumlah data, $K=$ jumlah variabel independen. Maka ditemukan nilai $d_{1}=1,6775$ dan nilai $d_{u}=1,7876$. Dengan demikian setelah diperhitungkan dan dibandingkan dengan tabel Durbin Watson, nilai Durbin Watson sebesar 1,982 berada diantara $\mathrm{d}_{1}$ dan $4-\mathrm{d}_{\mathrm{u}}$, yakni 1,6775 $<1,982<2,2124$. Dapat disimpulkan bahwa tidak terjadi autokorelasi pada model regresi dalam penelitian ini.

Uji multikolinearitas dilakukan dengan melihat angka Collinearity Statistic yang ditunjukkan oleh nilai tolerance dan nilai VIF. Kriteria umum yang digunakan adalah jika nilai tolerance $>0,10$ atau VIF $<10$ maka tidak terdapat gejala multikolinearitas. Hasil pengujian pada Tabel 2 menunjukkan nilai tolerance semua variabel memiliki nilai yang lebih besar dari 0,10, yaitu 0,515 untuk variabel kekayaan daerah, 0,730 untuk variabel belanja modal, dan 0,393 untuk variabel legsilative power. Sedangkan untuk nilai VIF memiliki nilai yang lebih kecil dari 10, yaitu 1,940 untuk variabel kekayaan daerah, 1,369 untuk variabel belanja modal, dan 2,543 untuk variabel legislative power. Maka berdasarkan uraian dapat disimpulkan bahwa tidak terdapat multikolinearitas antara variabel-variabel independen.

Model regresi yang digunakan dalam penelitian ini adalah MRA (Modetared Regresion Analysis). MRA merupakan aplikasi khusus regresi linear berganda dimana dalam persamaan regresinya mengandung unsur interaksi antara dua 
atau lebih variabel independen. Berdasarkan pengolahan data dengan menggunakan program SPSS diperoleh hasil sebagai berikut:

Tabel 3. Hasil Uji Hipotesis

\begin{tabular}{|c|c|c|c|c|c|}
\hline \multirow[t]{2}{*}{ Model } & \multicolumn{2}{|c|}{$\begin{array}{l}\text { Unstandardized } \\
\text { Coefficients }\end{array}$} & \multirow[t]{2}{*}{$\begin{array}{l}\text { Standardized } \\
\text { Coefficients }\end{array}$} & \multirow[t]{2}{*}{$\mathrm{T}$} & \multirow[t]{2}{*}{ Sig. } \\
\hline & B & Std. Error & & & \\
\hline (Constant) & .509 & .482 & & 1.056 & .293 \\
\hline LnKekayaan & .065 & .063 & 1.661 & 1.038 & .301 \\
\hline BelanjaModal & 1.875 & 696 & 1.460 & 2.693 & .008 \\
\hline LegislativePower & .138 & .057 & 1.333 & 2.420 & .017 \\
\hline Moderat1(X1.Z) & -.006 & .007 & -1.415 & -.827 & .409 \\
\hline Moderat2(X2.Z) & -.286 & .089 & -1.693 & -3.196 & .002 \\
\hline $\begin{array}{l}\text { Adjusted R } \\
\text { Square }\end{array}$ & 253 & & & & \\
\hline
\end{tabular}

Sumber: Data Penelitian, 2019

Dari Tabel 3 dapat dilihat hasil regresi untuk variabel kekayaan daerah memiliki nilai signifikansi 0,301 dimana nilai tersbut lebih besar dari 0,05. Hal ini berarti bahwa kekayaan daerah tidak berpengaruh secara signifikan terhadap kinerja penyelenggaraan pemerintah daerah. Dengan demikian, maka H1 yang diajukan tidak terdukung. Tidak berpengaruhnya kekayaan daerah terhadap kinerja penyelenggaraan pemerintah daerah mengindikasi bahwa peran total aset dalam meningkatkan kinerja penyelenggaraan pemerintah daerah belum berjalan sebagaimana mestinya. Pemerintah daerah masih belum mampu untuk mengelola aset yang dimiliki dengan baik. Menurut Niken (2013) terdapat beberapa permasalahan dalam pengelolaan aset lancar yang ada pada pemerintah daerah. Contoh permasalahan dalam pengelolaan aset lancar yang sering terjadi pada pemerintah daerah adalah penggunaan kas untuk kepentingan pribadi dari bendahara, selain itu masih terdapat permasalahan dalam penatausahaan persediaan yang ada (http://m.tribunnews.com/bisnis/bpk-temukan-indikasi-87-pemda-

bermasalah-dengan-aset-lancarnya, 2017). Penggunaan kas untuk kepentingan pribadi bendahara dapat merugikan masyarakat karena penyalahgunaan kas tersebut dapat menghambat tujuan yang telah direncanakan dan ditetapkan sebelumnya.

Menurut Marfiana dan Kurniasih (2013) daerah yang kaya akan memiliki kekuatan finansial yang besar dalam menunjang kinerjanya, namun dengan semakin besarnya total aset yang dimiliki dapat menimbulkan masalah keagenan yang lebih besar. Hal ini disebabkan karena dengan semakin besarnya total aset yang dimiliki oleh daerah akan membuat pemerintah daerah kesulitan untuk melakukan pengawasan terhadap masing-masing aset tersebut. Kesulitan dalam pengawasan tersebut dapat menyebabkan terjadinya penyalahgunaan terhadap aset yang ada, sehingga tidak akan mempengaruhi kinerja penyelenggaraan pemerintah daerah. Penelitian ini sejalan dengan penelitian yang dilakukan oleh Nugroho dan Prasetyo (2018), Marfiana dan Kurniasih (2013), Harumiati dan Payamta (2014) dan Ayuningsih (2016) yang menemukan bahwa kekayaan daerah yang diproksikan dengan total aset tidak berpengaruh signifikan terhadap kinerja penyelenggaraan pemerintah daerah. 
Variabel belanja modal mempunyai nilai signifikansi 0,008. Nilai tersebut lebih kecil dari 0,05, sehingga dapat disimpulkan bahwa belanja modal berpengaruh positif dan signifikan terhadap kinerja penyelenggaraan pemerintah daerah. Berdasarkan temuan tersebut maka $\mathrm{H} 2$ yang diajukan dalam penelitian ini terdukung. Berdasarkan teori pengeluaran pemerintah, terdapat perilaku pemerintah tentang pengeluaran/belanja pemerintah yaitu Median Voter Model. Median Voter Model menjelaskan bahwa pemerintah akan menentukan anggaran belanjanya sesuai dengan kepentingan terbaik konstituen. Pemerintah daerah akan berupaya untuk meningkatkan alokasi belanja modal guna meningkatkan pelayanan kepada masyarakat yang telah memilihnya. Belanja modal berhubungan erat dengan investasi pemerintah daerah yaitu dengan disediakannya fasiltias serta infrastruktur yang berkaitan langsung dengan pelayanan yang diberikan kepada masyarakat. Besarnya alokasi belanja modal dapat mencerminkan semakin banyak sarana dan prasarana yang dibangun untuk kepentingan publik. Dengan semakin banyaknya pembangunan yang dilakukan oleh pemerintah daerah selaku agen maka akan meningkatkan pelayanan yang diberikan kepada masyarakat yang merupakan principal, sehingga akan diikuti dengan meningkatnya kinerja penyelenggaraan pemerintah daerah.

Menurut Keynesian theory belanja yang dilakukan oleh pemerintah daerah merupakan suatu kebijakan perekonomian yang akan berdampak terhadap pertumbuhan ekonomi. Selajan dengan Keynesian theory dimana belanja modal merupakan pengeluaran pemerintah yang memberikan kontribusi terhadap peningkatan pendapatan daerah tersebut. Pembangunan infrastruktur yang dilakukan oleh pemerintah daerah berupa fasilitas umum merupakan contoh dari kegiatan belanja modal yang diharapkan dapat meningkatkan pertumbuhan pendapatan daerah yang nantinya akan berdampak terhadap pertumbuhan perekonomian di daerah tersebut. Dengan semakin besarnya belanja modal yang digunakan untuk keperluan-keperluan produktif daerah akan mampu untuk meningkatkan perekonomian di daerah tersebut. Hal ini nantinya akan berimplikasi terhadap meningkatnya kinerja penyelenggaraan pemerintah daerah. Penelitian ini sejalan dengan penelitian yang dilakukan oleh Andirfa et al. (2016), Leki et al. (2018) dan Mangkunegara (2015) yang menyatakan bahwa belanja modal berpengaruh positif dan signifikan terhadap kinerja pemerintah daerah.

Untuk variabel legislative power jika dilihat pengaruh langsungnya secara parsial terhadap kinerja penyelenggaraan pemerintah daerah, maka legislative power memiliki pengaruh yang signifikan terhadap kinerja penyelenggaraan pemerintah daerah. Hal ini bisa dilihat dari nilai signifikansinya sebesar 0,017 yang lebih kecil daripada 0,05.

Berdasarkan Tabel 3 juga dapat dilihat bahwa variabel moderat1 (interaksi kekayaan daerah dan legislative power) memiliki nilai signifikansi yang lebih besar dari 0,05 yaitu sebesar 0,409. Hal ini berarti bahwa interaksi antara kekayaan daerah dengan legislative power tidak berpengaruh secara signifikan terhadap kinerja penyelenggaraan pemerintah daerah. Dengan demikian, maka H4 yang diajukan dalam penelitian ini tidak terdukung. Pengelolaan kekayaan daerah tidak dapat lepas dari pengawasan DPRD sesuai dengan fungsi, tugas 
dan kewenangannya yang telah diamanatkan dalam peraturan perundangundangan yang berlaku. Namun peran DPRD dalam melakukan pengawasan terhadap pengelolaan kekayaan daerah belum terlaksana dengan optimal (Mutiah, 2008). Hal ini dapat dilihat dari masih terdapatnya beberapa permasalahan dalam pengelolaan aset lancar, sepeti penyalahgunaan kas dan pemasalahan dalam penatausahaan persediaan yang ada di Pemda.

Berikutnya, menurut teori keagenan terdapat hubungan keagenan antara legislatif dengan masyarakat. Legislatif diharapkan mampu mewakili kepentingan masyarakat (principalnya) ketika melaksanakan tugasnya. Pada kenyataannya, legislatif tidak selalu memiliki tujuan yang sama dengan masyarakat (Abdullah dan Asmara, 2008). Anggota legislatif mempunyai power dalam melaksanakan kekuasaannya, ini disebabkan karena anggota legislatif lebih memiliki banyak informasi terkait kekayaan daerah yang ada dibandingkan dengan masyarakat. Hal ini dapat menyebabkan peluang untuk melakukan moral hazard bagi anggota legislatif selaku agen dari publik. Penelitian yang dilakukan Hartanti (2018) menemukan bahwa ketika melakukan pengadaan barang milik daerah kebanyakan dari anggota legislatif akan melakukan tindakan penyalahgunaan kekuasaan untuk memaksimalkan keuntungannya. Anggota legislatif akan ikut campur pada saat pelelangan pengadaan barang milik daerah dengan cara memberikan instruksi kepada kepala bagian perlengkapan atau panitia lelang untuk memenangkan perusahaan atau rekanan yang diinginkan. Hal ini membuat hasil dari pengadaan barang milik daerah banyak yang tidak sesuai dengan yang diinginkan. Dengan demikian, semakin banyaknya jumlah anggota legislatif dapat membuat terjadinya moral hazard yang lebih besar terhadap pengelolaan kekayaan daerah yang ada sehingga dapat menyebabkan penurunan kinerja penyelenggaraan pemerintah daerah.

Dari Tabel 3 dapat terlihat nilai signifikansi variabel moderat2 (interaksi belanja modal dan legislative power) sebesar 0,002. Nilai tersebut lebih kecil dari nilai signifikansi 0,05, sehingga dapat disimpulkan bahwa interaksi antara belanja modal dan legislative power berpengaruh signifikan terhadap kinerja penyelenggaraan pemerintah daerah. Namun arah koefisien regresi negatif, sehingga tidak sesuai dengan $\mathrm{H} 5$ yang diajukan. Hasil penelitian ini menyimpulkan bahwa variabel legislative power dapat memperlemah hubungan belanja modal terhadap kinerja penyelenggaraan pemerintah.

Menurut penelitian yang dilakukan oleh Tanzi dan Davoodi (1997) terdapat perilaku oportunustik anggota legislatif terhadap kegiatan investasi publik. Anggota legislatif lebih menyukai belanja untuk investasi publik seperti pembangunan jalan dan jembatan dibandingkan dengan belanja untuk pelayanan pendidikan dan juga pelayanan kesehatan. Selain untuk mendapatkan komisi yang lebih besar, pembangunan jalan dan jembatan juga digunakan oleh anggota legislatif sebagai pemenuhan atas janji legislatif kepada pemilihnya. Hal ini dilakukan anggota legislatif untuk meningkatkan self interest, sehingga legsilatif selaku agen dari publik dapat berpeluang melakukan moral hazard. Artinya dengan semakin banyaknya jumlah anggota legislatif dapat menyebabkan terjadinya asimetri informasi terhadap penganggaran belanja modal, dimana anggota legislatif hanya berusaha untuk memaksimalkan 
keuntungannya tanpa mempertimbangkan kepentingan dan pelayanan kepada masyarakat. Hal ini akan membuat menurunnya kinerja penyelenggaraan pemerintah daerah.

Pada Tabel 3 juga dapat dilihat bahwa nilai Adjusted $R$ Square adalah sebesar 0,253 . Artinya sebesar $25,3 \%$ variabel kinerja penyelenggaraan pemerintah daerah dapat dijelaskan oleh kedua variabel independen, variabel legislative power dan kedua moderatnya, sedangkan sisanya dijelaskan oleh faktor-faktor diluar model.

\section{SIMPULAN}

Hasil penelitian penunjukkan bahwa kekayaan daerah tidak berpengaruh secara signifikan terhadap kinerja penyelenggaraan pemerintah daerah. Adapun belanja modal berpengaruh secara signifikan terhadap kinerja penyelenggaraan pemerintah daerah dengan arah positif. Variabel legislative power tidak dapat mempengaruhi hubungan antara kekayaan daerah dengan kinerja penyelenggaraan pemerintah daerah, sedangkan untuk hubungan antara belanja modal dengan kinerja penyelenggaraan pemerintah daerah variabel legislative power memperlemah hubungan tersebut.

Terdapat beberapa implikasi dari penelitian ini. Pertama, pemerintah daerah yang memiliki kekayaan daerah yang besar diharapkan dapat mengelola aset daerahnya dengan lebih baik lagi agar dapat meningkatkan penyelenggaraan urusan pemerintahan dan pemberian layanan kepada masyaraka. Kedua, pemerintah daerah diharapkan dapat mengoptimalkan dan menggali potensi PAD yang ada untuk mengurangi ketergantungan terhadap pemerintah pusat. Berikutnya, anggota legislatif diharapkan mampu untuk meningkatkan peran dan fungsi pengawasannya terhadap penyelenggaraan pemerintah daerah.

Penelitian ini memiliki berapa keterbatasan. Pertama, keterbatasan proksi yang digunakan dalam mengukur legislative power, yaitu hanya menggunakan jumlah anggota legislatif. Dimasa depan, riset sejenis dapat menggunakan proksi yang lebih komprehensif seperti menggunakan Parliamentary Power Index (PPI) yang dilakukan oleh Fish dan Kroenig tahun 2009. Kedua, penelitian ini tidak mengontrol faktor-faktor yang diduga ikut memengaruhi kinerja penyelenggaraan pemerintah daerah seperti regulasi daerah mengenai pelayanan publik.

\section{REFERENSI}

Alvini, Y., Y. M. Basri, dan M. A. Hasan. 2018. "Pengaruh Ukuran Pemerintah Daerah, Tingkat Kekayaan Daerah, Tingkat Ketergantungan Daerah kepada Pemerintah Pusat dan Belanja Modal terhadap Kinerja Keuangan Pemerintah Daerah (Studi pada Kabupaten/Kota se-Provinsi Riau Periode 2011- 2016)". JOM FEB, Vol. 1, No. 1, hlm: 1-15.

Andirfa, M., H. Basri, dan S. A. Majid. 2016. "Pengaruh Belanja Modal, Dana Perimbangan dan Pendapatan Asli Daerah terhadap Kinerja Keuangan Kabupaten dan Kota di Provinsi Aceh". Jurnal Magister Akuntansi, Vol. 5, No. 3, hlm.

Armaja, R. Ibrahim, dan Aliamin. 2015. "Pengaruh Kekayaan Daerah, Dana Perimbangan dan Belanja Daerah terhadap Kinerja Keuangan (Studi pada 
Kabupaten/Kota di Aceh)". Jurnal Perspektif Ekonomi Darussalam, Vol. 3, No. 2, hlm: 168-181.

Artha, R. D., P. Basuki, dan Alamsyah. 2015. "Pengaruh Karakteristik Pemerintah Daerah dan Temuan Audit BPK terhadap Kinerja Penyelenggaraan Pemerintahan Daerah (Studi Empiris Pada Pemerintah Kabupaten/Kota Di Provinsi NTB)". Jurnal InFestasi, Vol. 11, No. 2, hlm: 214-229.

Cheng, R. H. 1992. "An Empirical Analysis of Theories on Factors Influencing State Government Accounting Disclosure ". Journal of Accounting and Public Policy, Vol. II, No., hlm: 1-42.

Cooke, P. 1992. "Regional Innovation Systems, Assymetric Knowlage and Legacies of Learning". Center for Advanced Studies. University of Wales, Vol., No., hlm: 1-22.

Darise, N. 2007. Pengelolaan Keuangan Daerah. Jakarta: PT Indeks.

Febrianto, N. 2018. "Pengaruh Ukuran Pemerintah Daerah, Pendapatan Asli Daerah (PAD), Belanja Modal, Ukuran Legislatif, dan Intergovernmental Revenue terhadap Kinerja Keuangan Pemerintah Daerah (Studi Empiris pada Kabupaten dan Kota Di Provinsi D.I.Y Tahun 2009 - 2016)", Fakultas Ekonomi dan Bisnis, Universitas Muhammadiyah Surakarta, Thesis.

Harumiati, Y., dan Payamta. 2014. "Pengaruh Karakteristik Pemerintah Daerah dan Temuan Audit BPK terhadap Kinerja Pemerintah Daerah Kabupaten/Kota di Indonesia Tahun Anggaran 2011". Jurnal Akuntansi dan Pendidikan, Vol. 3, No. 2, hlm: 75-87.

Junita, A., dan S. Abdullah. 2016. "Pengaruh Fiscal Stress dan Legislature Size terhadap Ekspenditure Change pada Kabupaten/Kota di Sumatera Utara ". Jurnal Akuntansi dan Keuangan Indonesia, Vol. XX, No. 03, hlm: 467-478.

Kusumawardani, M. 2012. "Pengaruh Size, Kemakmuran, Ukuran Legislatif, Leverage terhadap Kinerja Keuangan Pemerintah Daerah di Indonesia". Accounting Analysis Journal, Vol. 1, No. 1, hlm: 27-35.

Lee, T. M., dan E. Plummer. 2007. "Budget Adjustment in Response to Spending Variance : Evidence of Ratcheting of Local Government Expenditure". Journal of Management Accounting Research, Vol. 19, No., hlm: 137-167.

Leki, Y., A. T. Naukoko, dan J. I. Sumual. 2018. "Pengaruh Pendapatan Asli Daerah dan Belanja Modal terhadap Kinerja Keuangan pada Pemerintah Kabupaten Halmahera Barat". Jurnal Berkala Ilmiah Efisiensi, Vol. 18, No. 5, hlm: 164-174.

Mangkunegara, I. 2015. "Pengaruh Karakteristik Keuangan dan Hasil Pemeriksaan pada Kesejahteraan Masyarakat di Provinsi Sumatera Utara". Jurnal Tata Kelola Akuntabilitas \& Keuangan Negara, Vol. 1, No. 2, hlm: 141-155.

Misra, F. 2008. "Investigasi dan Analisis Empiris Praktik Akuntansi Keuangan Pemerintah (Studi pada Kabupaten dan Kota di Propinsi Daerah Istemewa Yogyakarta dan Jawa Tengah)", Fakultas Ekonomika dan Bisnis Universitas Gadjah Mada, Thesis.

Mustikarini, W. A., dan D. Fitriasari. 2012. "Pengaruh Karakteristik Pemerintah Daerah dan Temuan Audit BPK terhadap Kinerja Pemerintah Daerah Kabupaten/Kota di Indonesia Tahun Anggaran 2007". Simposium Nasional Akuntansi, Vol. 15, No., hlm: 1-23. 
Nugroho, T. R., dan N. E. Prasetyo. 2018. "Pengaruh Karakteristik Pemerintah Daerah terhadap Kinerja Keuangan Pemerintah Daerah Kabupaten dan Kota di Jawa Timur". Jurnal Akuntansi dan Pendidikan, Vol. 7, No. 1, hlm: 27-34.

Renas, dan D. Muid. 2014. "Pengaruh Karakteristik Pemerintah Daerah dan Temuan Audit BPK terhadap Kinerja Pemerintah Daerah Studi pada Pemerintah Daerah Kabupaten/Kota di Provinsi Jawa Tengah Periode 2009-2011". DIPONEGORO JOURNAL OF ACCOUNTING, Vol. 4, No. 3, hlm: 1-15.

Siddi, P. 2016. "Peran Karakteristik Keuangan dan Opini Audit Dalam Meningkatkan Kinerja Penyelenggaraan Pemerintah Daerah". Jurnal Akuntansi Multiparadigma, Vol. 7, No. 3, hlm: 425-442.

Sijabat, H. 2016. "Pengaruh Opini, Temuan Audit, Kemandirian dan Ukuran Pemerintah Daerah terhadap Kinerja Penyelenggaraan Pemerintah Provinsi di Indonesia Tahun 2010-2014", Fakultas Ekonomi dan Bisnis Universitas Lampung, Thesis.

Sudarsana, H. S., dan S. N. Rahardjo. 2013. "Pengaruh Karakteristik Pemerintah Daerah dan Temuan Audit BPK terhadap Kinerja Pemerintah Daerah (Studi pada Pemerintah Kabupaten/Kota di Indonesia)". DIPONEGORO JOURNAL OF ACCOUNTING, Vol. 2, No. 4, hlm: 1-13.

Sumarjo, H. 2010. "Pengaruh Karakteristik Pemerintah Daerah terhadap Kinerja Keuangan Pemerintah Daerah (Studi Empiris pada Pemerintah Daerah Kabupaten/Kota di Indonesia)", Fakultas Ekonomi Universitas Sebelas Maret, Thesis.

UU No.23 Tahun 2014. Undang-Undang Republik Indonesia Nomor 23 Tahun 2014 tentang Pemerintahan Daerah Tambahan Lembaran Negara Republik Indonesia Nomor 5587.

UU No.32 Tahun 2004. Undang-Undang Republik Indonesia Nomor 32 Tahun 2004 tentang Pemerintahan Daerah. Tambahan Lembaran Negara Republik Indonesia Nomor 4437.

Widagdo, A. K. 2017. "Profil Kepala Daerah dan Kinerja Penyelenggaraan Pemerintah Daerah". Jurnal Ekonomi dan Bisnis, Vol. 20, No. 2, hlm: 303330. 